\title{
Increased organic acid production and decreased phytate phosphorus by high level of water content of Bacillus subtilis ATCC PTA-6737 fermentation of soybean meal
}

\author{
Sulhattin YASAR*1, Ramazan TOSUN ${ }^{1}$ \\ ${ }^{1}$ Department of Animal Science, Faculty of Agriculture, Igdir University, Şehid Bülent Yurtseven Yerleşkesi, \\ Suveren Igdir, 76000 Turkey \\ "corresponding author: sulhattin.yasar@gmail.com
}

Bulletin UASVM Animal Science and Biotechnologies 76(1)/ 2019

Print ISSN 1843-5262; Electronic ISSN 1843-536X

DOI:10.15835/buasvmcn-asb: 2018.0007

\begin{abstract}
In order to enrich soybean meal (SBM) by microbial fermentation, SBM (3 mm particle size) with 78 or $85 \%$ moisture content were inoculated with 0.0 or $1 \times 10^{7} \mathrm{CFU} / \mathrm{g}$ (colony forming unit) Bacillus subtilis ATCC PTA-6737 and fermented at $37{ }^{\circ} \mathrm{C}$ for $0,24,48$ and $72 \mathrm{~h}$. There was a marked decrease in $\mathrm{pH}$ with $85 \%$ moisture content, associated at higher organic acid production, compared to increased $\mathrm{pH}$ at $24 \mathrm{~h}$ with $78 \%$ moisture content and a gradual decrease hereafter. Bacterial growth peaked at $48 \mathrm{~h}$ with both moisture contents. Fermenting SBM increased crude ash level by $65 \%$, soluble amino acid nitrogen by 2.7 folds and degraded phytic acid by $65-75 \%$. Moreover, there was a high level of organic acid production despite of decreased crude protein by 6-7\%, but the effect of high moisture level was more pronounced in all case. In conclusion, fermentation SBM with water content of $85 \%$ at $35{ }^{\circ} \mathrm{C}$ by $B$. subtilis provided SBM an appreciable amount of bio-functionalities such reduced phytate content, increased soluble amino acid content and more importantly fortified with organic acids. The fermented SBM can therefore be used an antimicrobial agent due to its high organic acid level in animal nutrition.
\end{abstract}

Keywords: Bacillus subtilis, soybean meal, fermentation, nutrient composition

\section{Introduction}

Soybean meal (SBM) high in protein content is an important plant protein feed material in animal nutrition (Senkoylu et al., 2005), and the use of SBM is limited by the presence of some antinutritional factors (ANFs). In addition, the phosphorous of SBM is in the form of phytate which may not be well utilised by monogastric animals (Balloun, 1980 and Liener, 1980).

There has been high interest in testing the effects of microbial fermentation of SBM for enrichment of nutritional contents and degradation of ANFs in animal nutrition (Roubosvan den Hil et al., 2009; Roh et al., 2015; Chi and Cho 2016). In many studies, the size of peptides was reduced while digestibility of some amino acids was increased by microbial fermentation of SBM (Hong et al., 2004; Feng et al., 2007a). Fermentation of SBM with B. subtilis alone caused to increased protein and soluble proteins and decreased trypsin inhibitor (TI) (Dai et al., 2017). Feeding the diets containing fermented soybean meal (SBM) with B. subtilis BS12 with the reduced contents of antinutritional factors (ANFs) remarkably improved the performance and intestinal immune system of the piglets (Feng et al., 2007b and Zhang et al., 2018).

B. subtilis and Aspergillus oryzae were tested to ferment SBM (Teng et al., 2012). The increased contents of protein, small size proteins and 
antioxidant capacity and decreased contents of trypsin inhibitors and antigenic proteins were superior with B. subtilis than Aspergillus oryzae. Fermenting SBM with a mixture of $B$. subtilis, Hansenula anomala and Lactobacillus casei (2:1:2) was found a best microbial combination for increased peptide contents and reduced ANFs (Yuan et al., 2017). The replacement of SBM with fermented SBM with mixed microorganisms containing B. subtilis at a dietary level of $10 \%$ caused significantly increased animal performance and gut health in weaned piglets (Yuan et al., 2017 and Zhu et al., 2017).

All the above has clearly indicated that the use of $B$. subtilis is very promising microorganism for the improvement of SBM nutritional composition. Bacillus subtilis is a Gram-positive, found in soil and the gastrointestinal tract (Yonsel, 2010). B. subtilis is safe microorganism which has been widely used in many industrial microbial applications (Constantinescu and Petruta, 2015) as well as in food and feed industry (Yonsel, 2010). Solid state fermentation (SSF) using microorganisms is a process of immersed solid materials in absolute water (Özşölen, 2010 and Mukherjee et al., 2016) under an optimal temperature required for the species of microorganisms, and the effect of moisture content has been found important on nutrient enrichment of SBM (Gervais and Molin, 2003; Amadou et al., 2010; Rashid et al., 2011). In these studies, it was demonstrated that the ratio of added water to solid materials in SSF is crucial for improved metabolic activity of microorganism, and directly interacts together with oxygen for the removal of heat generated during the fermentation. In SSF, the water content of fermenting substrate is preferable above $60 \%$, and moreover the optimal level of water content in SBM fermentation studies ranged from 75 to $85 \%$ water content (Amadou et al., 2010; Yasar et al., 2018; Karakurt et al., 2019).

Therefore, the objective of this study was to test the effect of two levels of moisture (78 and 85\%) during the B. subtilis ATCC PTA-6737 fermentation on nutritional composition of SBM.

\section{Materials and methods}

B. subtilis ATCC PTA-6737 was purchased from ATCC (LGC Standards GmbH Mercatorstr. 51 46485 Wesel Germany) in the form of lyophilised pellet, which was cultured on Brain Heart Infusion Broth at $37{ }^{\circ} \mathrm{C}$ for $24 \mathrm{~h}$. Active cultured cells were suspended in saline solution after the centrifugation of $15000 \mathrm{rpm}$ at $4{ }^{\circ} \mathrm{C}$ for $10 \mathrm{~min}$. The suspension was collected in the required quantity used as inoculant in the fermentation process. A spread plate method using nutrient agar (Merck 1.05450) was used to determine the total number of CFU (colony forming unit) of $B$. subtilis according to the standard protocol of EN ISO 2009. The sterile wet sample taken under aseptic conditions was suspended $(1: 10 \mathrm{w} / \mathrm{v})$ in a sterilised phosphate buffered saline. The suspended solution was serially diluted, and then spread on nutrient agar plates for incubation at $37^{\circ} \mathrm{C}$ for $24 \mathrm{~h}$. The CFU was counted and calculated per g of wet mass (EN ISO 2009).

Soybean meal was bought in $20 \mathrm{~kg}$ from a local feed mill in air-dried form (90\% dry matter) and ground to pass a 3-mm sieve. A 200 gram of ground homogenous SBM was autoclaved at $121^{\circ} \mathrm{C}$ for $20-25$ min for SSF conducted in Pyrex Erlenmeyer flask of $1000 \mathrm{ml}$. The moisture content of SBM with or without bacteria inoculants were adjusted to 78 and $85 \%(\mathrm{w} / \mathrm{w}$ ) by adding sterilised distilled water. Finally, a freshly prepared bacteria suspension was added at a rate of $1 \times 10^{7} \mathrm{CFU}$ per g solid material, and homogenously mixed under a flow-cabinet. The flasks covered with sterilised cotton and aluminium folio were left for fermentation at $37^{\circ} \mathrm{C}$ for $0,24,48$ and $72 \mathrm{~h}$ at which each flask was stirred with sterilised glass rods for 5 min under the flow cabinet. The experimental design was of 2 moisture levels (78 and 85\%) x 3 replicates of flasks $\times 4$ incubation periods $(0,24$, 48 and $72 \mathrm{~h}$ ). At the end of each incubation period, $\mathrm{pH}$ values of fermenting substrate were measured. The wet samples were immediately taken for the determination of bacteria count (ISO 2004). The remaining wet samples were dried at a constant temperature of $50{ }^{\circ} \mathrm{C}$ until a constant weight of sample was obtained for the determination of dry matter content. The crude protein and crude ash was determined by the methods of AOAC (1990). The content of soluble amino nitrogen and organic acids (mainly acetate, lactate and butyrate) were determined by the methods reported by Karabulut and Canbolat (2005). The method of Karabulut and Canbolat (2005) suitable to silage and fermented products was modified to quantify individual organic acids. Ten grams of homogenous SBM samples were diluted 10 times in distilled water prior to incubation at $50{ }^{\circ} \mathrm{C}$ for $30 \mathrm{~min}$ at 150 
rpm. Then the supernatants were collected after a centrifugation at $4100 \mathrm{rpm}$ and were immediately steam distilled. Three subsequent distillates were collected. The last distillate was obtained after an oxidation of the remaining supernatant from first two distillates in a potassium dichromate solution. All distillates were then titrated with $0.05 \mathrm{~N} \mathrm{NaOH}$. The amount of $\mathrm{NaOH}$ consumed was used to calculate individual organic acids of acetic, butyric, and lactic acids, and total organic acid (\% of sample DM) were expressed as sum of acetic, butyric, and lactic acids of all samples (Karabulut and Canbolat 2005). Phytate content was determined spectrophotometrically by the method of De Boland et al. (1975). The fine samples were extracted for $18-24 \mathrm{~h}$ with a solution containing $1.2 \% \mathrm{HCL}$ and $10 \% \mathrm{Na}_{2} \mathrm{SO}_{4}$. Then 10 $\mathrm{ml}$ of extract was treated with $10 \mathrm{ml}$ water and $5 \mathrm{ml}$ of $0.4 \% \mathrm{FeCl}_{3}$ in $0.6 \% \mathrm{HCL}$ containing $5 \%$ $\mathrm{Na}_{2} \mathrm{SO}_{4}$. The phosphorous content of insoluble ferric salts was determined colorimetrically after digestion in $3 \mathrm{ml} \mathrm{H}_{2} \mathrm{SO}_{4}$ and $5 \mathrm{ml}$ nitric acid. Three independent samples (flasks) taken at the end of each fermentation period were analysed triplicate, resulting in $9(3 \times 3)$ independent measurements per treatment.

A general linear model (GLM) was used to test the effect of water levels on the studied parameters using SPSS statistical program (IBM SPPS Inc, version 23), where the differences between the treatments were separated by Duncan' Multiple Comparison Test at a 0.05 significance level.

\section{Results and discussions}

The effect of moisture content on $\mathrm{pH}$ of fermenting substrate was significant $(P<0.05)$. The $\mathrm{pH}$ values at $78 \%$ moisture condition significantly $(P<0.05)$ increased at $24 \mathrm{~h}$, and then gradually decreased to the same $\mathrm{pH}$ of the $0 \mathrm{~h}$ of fermentation (Tab. 1). Initially, there was an increase in $\mathrm{pH}$ at 24 $\mathrm{h}$ of fermentation with low moisture level (78\%) in which there were no changes in total organic acid production. However, the level of acetic acid decreased significantly $(P<0.05)$ whereas the production of lactic acid increased during the 24 $\mathrm{h}$ of fermentation. On the other hand, fermenting SBM with $85 \%$ moisture level gradually caused a significant $(P<0.05)$ decrease in $\mathrm{pH}$. In parallel, the production of organic acids significantly $(P<0.05)$ changed with the changes in the $\mathrm{pH}$ of SBM at both levels of moisture contents. In both 78 and
85\% moisture conditions, a maximum bacteria growth from $10^{7}$ to $10^{10} \mathrm{CFU} / \mathrm{g}$ occurred at $48 \mathrm{~h}$ of fermentation, and then lowered gradually (Tab. 1). B. subtilis usually grows at a $\mathrm{pH}$ range from 5.5 to 8.5 (Sneath, 1986), and pH values in the current study were within these ranges. It was earlier shown that fermentation with $B$. subtilis of SBM caused increased alkaline protease production which may have a proteolytic effect on ammonia release, and thereby increased pH (Sarkar et al., 1993 and Chantawannakul et al., 2002). This indicated that even though the bacteria used in our study could have an alkaline protease activity during $24 \mathrm{~h}$ due to an initial increase in $\mathrm{pH}$ over 6.0 (Abusham et al., 2009) the significant drops in $\mathrm{pH}$ after $24 \mathrm{~h}$ in both SFM samples differed in moisture content clearly indicated the suitability of fermentation for the organic acid production rather than an activity of protease which was not measured in this study. Thus, there is a high level of organic acid production which was parallel to decreased $\mathrm{pH}$ of the substrate in our study at both levels of moisture contents. Many species of Bacillus were reported to produce more lactic acids in anaerobic than aerobic fermentation (Ohara and Yahata, 1996), similar to our study conducted at anaerobic condition. Moreover, the production of organic acids in our study was high in the case of high moisture condition. This result was found contradictory to the results reported by Yasar et al. (2018), using the same strain of B. subtilis to ferment sunflower meal. However, Ohara and Yataha (1996) reported lactic acid production by $B$. spp., fermentations, similar to our results. Furthermore, Karakurt et al., (2019) demonstrated clearly that fixing $\mathrm{pH}$ at around 5.5 for Bacillus subtilis fermentation of both sunflower and soybean meal samples produced an appreciable amount of organic acids in the form of acetate, butyrate and lactate, similar to the results of $\mathrm{pH}$ and organic acids obtained from both moisture levels at 48 and $72 \mathrm{~h}$ of fermentation in our experiment.

Dry matter contents of SFM with 78\% moisture content were significantly $(\mathrm{P}<0.05)$ increased at 48 and $72 \mathrm{~h}$ of the fermentation. The increase in dry matter content of SFM with $85 \%$ moisture content was insignificant $(P>0.05)$. There were similarly significant $(P<0.05)$ increases in crude ash contents of SFM with both moisture contents. Phytic acid considered as ANF in monogastric 
Table 1. Changes in $\mathrm{pH}$, bacteria count (CFU/g) and organic acids (\%) of fermented SBM

\begin{tabular}{cccccc}
\hline Time $(\mathrm{h})$ & $\mathrm{pH}$ & Bacteria count CFU/g & Acetic acid \% & Butyric acid \% & Lactic acid \% \\
\hline \multicolumn{7}{c}{$78 \%$ moisture content } \\
\hline 0 & $6.28 \pm 0.01^{\mathrm{a}}$ & $1 \times 10^{7} \pm 0.05^{\mathrm{a}}$ & $4.2 \pm 0.12^{\mathrm{a}}$ & $0.0 \pm 0.0^{\mathrm{a}}$ & $0.0 \pm 0.0^{\mathrm{a}}$ \\
\hline 24 & $7.02 \pm 0.02^{\mathrm{b}}$ & $5.0 \times 10^{10} \pm 0.02^{\mathrm{b}}$ & $1.43 \pm 0.032^{\mathrm{b}}$ & $0.00 \pm 0.00^{\mathrm{a}}$ & $2.75 \pm 0.03^{\mathrm{b}}$ \\
\hline 48 & $6.60 \pm 0.01^{\mathrm{c}}$ & $6.4 \times 10^{10} \pm 0.03^{\mathrm{c}}$ & $9.47 \pm 0.93^{\mathrm{c}}$ & $0.73 \pm 0.01^{\mathrm{c}}$ & $3.42 \pm 0.023^{\mathrm{b}}$ \\
\hline 72 & $6.30 \pm 0.01^{\mathrm{a}}$ & $3.6 \times 10^{10} \pm 0.10^{\mathrm{d}}$ & $4.54 \pm 0.03^{\mathrm{d}}$ & $0.96 \pm 0.01^{\mathrm{d}}$ & $7.58 \pm 0.05^{\mathrm{c}}$ \\
\hline \multicolumn{7}{c}{$85 \%$ moisture content } \\
\hline 0 & $6.28 \pm 0.01^{\mathrm{a}}$ & $1 \times 10^{7} \pm 0.05^{\mathrm{a}}$ & $4.2 \pm 0.12^{\mathrm{a}}$ & $0 \pm 0.0^{\mathrm{a}}$ & $0.0 \pm 0.0^{\mathrm{a}}$ \\
\hline 24 & $6.04 \pm 0.02^{\mathrm{b}}$ & $4.4 \times 10^{10} \pm 0.1^{\mathrm{b}}$ & $6.97 \pm 0.08$ & $0.0 \pm 0.0^{\mathrm{b}}$ & $1.77 \pm 0.027^{\mathrm{b}}$ \\
\hline 48 & $5.74 \pm 0.01^{\mathrm{c}}$ & $7.3 \times 10^{10} \pm 0.15^{\mathrm{c}}$ & $7.83 \pm 0.04$ & $0.0 \pm 0.0^{\mathrm{c}}$ & $8.45 \pm 0.06^{\mathrm{c}}$ \\
\hline 72 & $5.28 \pm 0.01^{\mathrm{d}}$ & $5.3 \times 10^{7} \pm 0.02^{\mathrm{d}}$ & $7.97 \pm 0.05^{\mathrm{c}}$ & $2.08 \pm 1.07^{\mathrm{d}}$ & $7.48 \pm 4.55^{\mathrm{c}}$ \\
\hline Note:Differentlettersinthe & & & &
\end{tabular}

Note: Different letters in the same column indicated significant (Duncan test, $P<0.05$ ) differences between the means \pm standard deviation.

Table 2. Effect of fermenting SBM at two levels of moisture content on nutritional composition

\begin{tabular}{|c|c|c|c|c|c|}
\hline Parameters \% & Moisture \% & 0 & 24 & 48 & 72 \\
\hline \multirow{2}{*}{ Dry matter } & 78 & $21.35 \pm 0.25^{\mathrm{ax}}$ & $21.38 \pm 0.10^{\mathrm{ax}}$ & $23.40 \pm 0.26^{\mathrm{bX}}$ & $23.35 \pm 0.90^{\mathrm{bx}}$ \\
\hline & 85 & $15.15 \pm 0.15^{\mathrm{aY}}$ & $15.05 \pm 0.03^{\mathrm{aY}}$ & $15.75 \pm 0.6^{\mathrm{aY}}$ & $15.55 \pm 0.5^{\mathrm{aY}}$ \\
\hline \multirow{2}{*}{ Crude ash } & 78 & $6.30 \pm 0.4^{\mathrm{aX}}$ & $8.9 \pm 0.6^{\mathrm{bX}}$ & $9.97 \pm 0.03^{c x}$ & $10.57 \pm 0.2^{\mathrm{dX}}$ \\
\hline & 85 & $6.3 \pm 0.4^{\mathrm{aX}}$ & $9.3 \pm 0.02^{\mathrm{bY}}$ & $9.9 \pm 0.44^{\mathrm{cX}}$ & $10.1 \pm 0.37^{c X}$ \\
\hline \multirow{2}{*}{ Crude protein } & 78 & $51.3 \pm 0.3^{\mathrm{aX}}$ & $51.0 \pm 0.5^{\mathrm{ax}}$ & $51.5 \pm 0.2^{\mathrm{ax}}$ & $51.3 \pm 0.5^{\mathrm{ax}}$ \\
\hline & 85 & $51.3 \pm 0.3^{\mathrm{aX}}$ & $47.8 \pm 0.4^{\mathrm{bX}}$ & $49.4 \pm 0.4^{\mathrm{cY}}$ & $47.1 \pm 0.2^{\mathrm{bY}}$ \\
\hline \multirow{2}{*}{$\begin{array}{c}\text { Soluble amino } \\
\text { nitrogen }\end{array}$} & 78 & $4.8 \pm 0.25^{\mathrm{aX}}$ & $12.53 \pm 0.35^{\mathrm{bX}}$ & $14.71 \pm 0.04^{c X}$ & $13.90 \pm 0.15^{c x}$ \\
\hline & 85 & $4.8 \pm 0.25^{\mathrm{aX}}$ & $13.68 \pm 0.11^{\mathrm{aY}}$ & $18.60 \pm 0.39^{\mathrm{bY}}$ & $17.0 \pm 0.75^{\mathrm{Cy}}$ \\
\hline \multirow[t]{2}{*}{ Phytic acid } & 78 & $1.22 \pm 0.05^{\mathrm{aX}}$ & $1.18 \pm 0.04^{\mathrm{aX}}$ & $0.76 \pm 0.01^{\mathrm{bX}}$ & $0.33 \pm 0.01^{\mathrm{cX}}$ \\
\hline & 85 & $1.22 \pm 0.05^{\mathrm{aX}}$ & $1.25 \pm 0.06^{\mathrm{aX}}$ & $0.82 \pm 0.04^{\mathrm{dX}}$ & $0.43 \pm 0.02^{\mathrm{eY}}$ \\
\hline
\end{tabular}

Note: Different letters in the same column indicated significant (Duncan test $P<0.05$ ) differences between the means \pm standard deviation. Different letters in the same row indicated significant (Duncan test $P<0.05$ ) differences between the means \pm standard deviation.

animals were remarkably degraded up to 65 to $75 \%$ with fermentation of SBM at both moisture contents in the present study. The percentage increase in crude ash content in this study was about $65 \%$. The changes in crude protein content of SBM with $78 \%$ moisture level was not significant, but the crude protein content was decreased by $6-7 \%$ after $24 \mathrm{~h}$ of fermentation with $85 \%$ moisture content. Fermentation with $85 \%$ water content caused more increases ( 2.7 folds) in soluble amino nitrogen content than the increase with fermentation with $78 \%$ water content $(2.0$ folds).

It was earlier reported that anaerobic fermentation of Bacillus spp., grown on polypepton obtained from soybean produced appreciable amount of organic acids (Ohara and Yahata, 1996). And, Bacillus spp. can degrade macro nutrient to water-soluble low molecular weight components (Kiers et al., 2000). These indicated that fermentation of SBM in high level of moisture content in our study caused significantly increased soluble amino nitrogen with low molecular weight used by microorganisms to produce high levels of organic acids, thereby lead to a reduced level of crude protein up to $6-7 \%$. This result was found contradictory to the increased level of crude protein with Bacillus subtilis fermentation of SBM (Teng et al., 2012; Dai et al., 2017; Yuan et al., 2017). This difference was basically due to the high moisture content of fermenting substrate in the present study. The fermentation increased amount of soluble amino nitrogen in the SBM samples and the more production of soluble amino nitrogen the more digestibility of SBM in animal nutrition. In this study fermented SBM containing less phytate and enriched with organic acid may have a high potentiality used in animal nutrition as functional feed materials, similar to the cases reported by Yuan et al. (2017) and Zhu et al. (2017). Organic acids were used as antimicrobial agents in the diet of farm animals (Weber et al., 2012; Meeusen and 
Hagemans, 2010; Torallardona et al., 2016). On the other hand, the fermentation of SBM at both moisture contents increased crude ash content and amount of small size protein molecules (soluble amino nitrogen) which are almost water soluble, and decreased amount of phytic acid, which were also supported by earlier results (Teng et al., 2012; Dai et al., 2017; Yuan et al., 2017).

In conclusion, the results showed that the higher water content in SSF of SBM the higher decreased crude protein content, but the more production of organic acids and soluble amino nitrogen, and that the SSF of SBM with 78 to $85 \%$ water content lead to significant degradation of phytic acid. We recommend that the fermented SBM containing appreciable amount of organic acid could be used as functional feed material for a better animal performance and health.

Acknowledgments. The authors thank to Suleyman Demirel Universitesi Rektörlüğü, Bilimsel Araştırma Projeleri Birimi, Isparta, Turkey to provide a financial support to the study (Project no: 4339-M2-15).

\section{References}

1. Abusham A, Rahman RNZRA, Salleh AB, Basri M 2009 Optimization of physical factors affecting the production of thermo-stable organic solvent-tolerant protease from a newly isolated halo tolerant Bacillus subtilis strain Rand. Microbial Cell Factories, 8: 20 doi:10.1186/1475-2859-820.

2. Amadou I, Kamara MT, Tidjani A, Foh MBK, Guo-Wei L (2010). Physicochemical and Nutritional Analysis of Fermented Soybean Protein Meal by Lactobacillus plantarum Lp6. World Journal of Dairy and Food Sciences, 5: 114-118.

3. AOAC (1990). Official Methods of Analysis. Association of Official Analytical Chemists. 15th Edition.

4. Balloun SL (1980). Soybean Meal in Poultry Nutrition. K.C. Lepley, ed. The Ovid Bell Press, Inc., Fulton, Missouri.

5. Chantawannakul P, Oncharoen A, Klanbut K, Chukeatirote E, Lumyong S (2002). Characterization of proteases of Bacillus subtilis strain 38 isolated from traditionally fermented soybean in Northern Thailand. Science Asia, 28 : 241-245

6. Chi $\mathrm{CH}$, Cho SJ (2016). Improvement of bioactivity of soybean meal by solid state fermentation with Bacillus amyloliquefaciens versus Lactobacillus spp. and Saccharomyces cerevisiae. LWT-Food Science Technology, 68: 619-625.

7. Constantinscu AF, Petruta CC (2015). Biodiversity of Bacillus subtilis group and beneficial traits of Bacillus species useful in plant protection, Romanian Biotechnological Letters, Vol. 20, No. 5, 2015, ss. 10737 10750, s.10738.
8. Dai $\mathrm{CH}, \mathrm{Ma} \mathrm{R}, \mathrm{He}$ L, Huang S, Zhu Q, Ding LL (2017). Improvement of nutritional value and bioactivity of soybean meal by solid-state fermentation with Bacillus subtilis. LWT-Food Science Technology, 86:1-7. https:// doi.org/10.1016/j.lwt.2017.07.041.

9. De Boland AR, Garner GB, O Dell BL (1975). Identification and properties of phytate in cereal grains and oil seed products. Journal of Agricultural and Food Chemistry, 23: 1186- 1189.

10. EN ISO (2004). No. 7932 (Microbiology of food and animal feeding stuffs - Horizontal method for the enumeration of presumptive Bacillus cereus - Colony-count technique at $30^{\circ} \mathrm{C}$ ). European Committee for Standardization, Brussels.

11. Feng J, Liu X, Xu ZR, Liu YY, Lu YP (2007a). Effects of Aspergillus oryzae 3.042 fermented soybean meal on growth performance and plasma biochemical parameters in broilers. Animal Feed Science and Technology,134: $235-242$.

12. Feng J, Liu X, Xu Z, Lu Y, Liu Y (2007b). Effect of fermented soybean meal on intestinal morphology and digestive enzyme activities in weaned piglets. Digestive Diseases and Sciences, 52: 1845-1850. doi:10.1007/s10620-0069705-0.

13. Gervais P, Molin P (2003). The Role of Water in Solid State Fermentation. Biochemical Engineering Journal, 13: 85101.

14. Hong KJ, Lee C, Kim HSW (2004). Aspergillus oryzae GB107 fermentation improves nutritional quality of food soybeans and soybean meals. Journal of Medical Food, 7: 430-435.

15. Karakurt Y, Guvercin D, Onder S, Celik C, Baran B, Tosun $R$, YASAR S (2019). Chemical, enzymatic and antioxidant enrichments of full-fat soybean and sunflower meal by Bacillus subtilis (ATCC® 6633) fermentation using a solid-state bioreactor. Turkish Journal of Veterinary and Animal Sciences, 43: 82-93. doi:10.3906/vet-1803-1

16. Kiers JL, Van laeken AEA, Rombouts FM, Nout MJR (2000). In vitro digestibility of Bacillus fermented soya bean. International Journal of Food Microbiology, 60: 163-169.

17. Liener IE (1980). Toxic Constituents of Plants Foodstuffs. Academic Press, New York.

18. Meeusen A, Hagemans D (2010). A Eubiotic Approach to Necrotic Enteritis in Broilers. Poultry International 49: 20-23. https://www.wattagnet.com/articles/5746-aeubiotic-approach-to-necrotic-enteritis-in-broilers.

19. Mukherjee R, Chakraborty R, Dutta A (2016). Role of Fermentation in Improving Nutritional Quality of Soybean Meal - A Review. Asian-Australasian Journal of Animal Sciences, 29: 1523-1529.

20. Ohara Y, Yahata M (1996). L-Lactic acid production by Bacillus spp in anaerobic and aerobic culture. Journal of Fermentation and Bioengineering 81: 272-274

21. Özșölen F (2010). Katı Faz Fermentasyonu ile Ligninolitik Enzimlerin Üretimi. Eskisehir Osmangazi Universitesi Fen Bilimleri Enstitüsü, Biyoloji Anabilim Dalı, 73s, Eskişehir.

22. Rashid JI, Samat N, Mohtar W, Yusoff W (2011). Optimization of temperature, moisture content and inoculum size in solid state fermentation to enhance 
mannanase production by Aspergillus terreus SUK-1 using RSM. Pakistan Journal of Biological Science, 14: 533-539.

23. Roh SG, Carroll JA, Kim SW (2015). Efects of fermented soybean meal on innate immunity-related gene expressions in nursery pigs acutely challenged with lipopolysaccharides. Animal Science Journal,86: 508-516.

24. Roubos-van den Hil PJ, Nout MJ, Beumer RR, Van Der Meulen J, Zwietering MH (2009). Fermented soya bean (tempe) extracts reduce adhesion of enterotoxigenic Escherichia coli to intestinal epithelial cells. Journal of Applied Microbiology, 106: 1013-1021.

25. Sarkar PK, Cook PE, Owens JD (1993) Bacillus fermentation of soybeans. World J Microbiol Biotechnol, 9: 295-299.

26. Senkoylu N, Samli HE, Akyurek H, Agma A, Yasar S (2005). Use of High Levels of Full-Fat Soybeans in Laying Hen Diets. Journal of Applied Poultry Research, 14: 32-37.

27. Sneath PHA (1986). Section 13. Endospore-forming Grampositive rods and cocci. In: Bergey's Manual of Systematic Bacteriology Vol 2, 9th ed (Edited by Sneath PHA, Mair NS, Sharpe ME and Holt JG), 1104-39. Williams \& Wilkins, Baltimore, MD.

28. Teng D, Gao M, Yang Y, Liu B, Tian Z, Wang J (2012). Bio-modification of soybean meal with Bacillus subtilis or Aspergillus oryzae. Biocatalysis and Agricultural Biotechnology, 1: 32-38. DOI: 10.1016/j. bcab.2011.08.005.

29. Torallardona D, Broz J, Paulus C, Meuter A (2016). Efficacy of a Combination of Eubiotics in Escherichia coli $k 88$ Challenged Piglets. 2nd International Symposium on Alternatives to Antibiotics (ATA) Challenges and Solutions in Animal Production OIE Headquarters, Paris, France 1215 December 2016.

30. Weber GM, Michalczuk M, Huyghebaert G, Juin H, Kwakernaak C, Gracia MI (2012). Effects of a Blend of Essential Oil Compounds and Benzoic Acid on Performance of Broiler Chickens as Revealed by a MetaAnalysis of 4 Growth Trials in Various Locations. Poultry Science, 91: 2820-2828. doi: 10.3382/ps.2012-02243.

31. Yasar S, Uysal C and Tosun C (2018). Nutritional Fortification of Sunflower Meal by Bacillus Subtilis ATCC PTA-6737 Fermentation. Bulletin UASVM Animal Science and Biotechnologies, 75(2): 99-104. DOI: http://dx.doi. org/10.15835/buasvmcn-asb:2018.0008.

32. Yonsel Ş (2010). Bacillus subtilis İçeren Küf ve Bakterilere Karşı Koruyucu Biyosidal Ürün. 1. Ulusal Biyosidal Kongresi 4-7 Kasım, Antalya.

33. Yuan L, Chang J, Yin Q, Lu M, Di Y, Wang P, Wang Z, Wang E, Lu F (2017). Fermented soybean meal improves the growth performance, nutrient digestibility, and microbial flora in piglets. Animal Nutrition, 3: 19-24. https://doi. org/10.1016/j.aninu.2016.11.003.

34. Zhang Y, Shi C, Wang C, Lu Z, Wang F, Feng J, Wang Y (2018) Effect of soybean meal fermented with Bacillus subtilis BS12 on growth performance and small intestinal immune status of piglets. Food and Agricultural Immunology, 29: 133-146. DOI: 10.1080/09540105.2017.1360258.

35. Zhu J, Gao M, Zhang R, Sun Z, Wang C, Yang F, Huang T, Qu S, Zhao L, Li Y, Hao Z (2017). Efects of soybean meal fermented by L. plantarum, B. subtilis and S. cerevisieae on growth, immune function and intestinal morphology in weaned piglets. Microbial Cell Factories, 16: 191. DOI 10.1186/s12934-017-0809-3. 